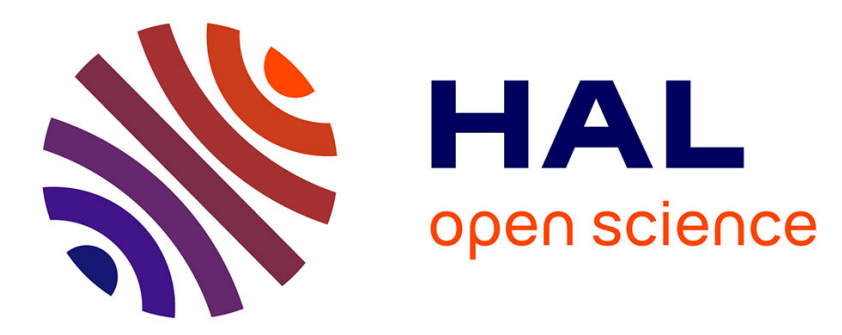

\title{
Do coworking spaces promise a revolution or spark revenge? A Foucauldian spatio-material approach to the re-spatialization of remote work in coworking spaces
}

Aurélie Leclercq-Vandelannoitte

\section{- To cite this version:}

Aurélie Leclercq-Vandelannoitte. Do coworking spaces promise a revolution or spark revenge? A Foucauldian spatio-material approach to the re-spatialization of remote work in coworking spaces. Nathalie Mitev (éd.). New Ways of Working - Organizations and Organizing in the Digital Age, Palgrave McMillan, pp.151-173, 2021. hal-03330208

\author{
HAL Id: hal-03330208 \\ https://hal.science/hal-03330208
}

Submitted on 31 Aug 2021

HAL is a multi-disciplinary open access archive for the deposit and dissemination of scientific research documents, whether they are published or not. The documents may come from teaching and research institutions in France or abroad, or from public or private research centers.
L'archive ouverte pluridisciplinaire HAL, est destinée au dépôt et à la diffusion de documents scientifiques de niveau recherche, publiés ou non, émanant des établissements d'enseignement et de recherche français ou étrangers, des laboratoires publics ou privés. 


\title{
Do coworking spaces promise a revolution or spark revenge?
}

\section{A Foucauldian spatio-material approach to the re-spatialization of remote work in coworking spaces}

\author{
Aurélie LECLERCQ-VANDELANNOITTE \\ CNRS (LEM, Lille Economie Management, UMR 9221), IESEG School of Management \\ a.leclercq@ieseg.fr
}

\begin{abstract}
Beyond virtualization and anytime-anywhere rhetoric, the movement toward the "respatialization" of work in various workplaces and new spaces for work, such as third workspaces, results in hybridation. This spatial reconfiguration of work has been poorly theorized, failing to address the meaning and implications of such re-spatialization of work and its consequent re-regulation. This study focuses on the re-spatialization and re-regulation of remote work in coworking spaces, increasingly used by companies to rematerialize the activity of their remote employees. In contextualizing this re-spatialization according to organizational politics, this chapter proposes a symbolic/narrative, material, and experienced tryptic, based on the thought of the French philosopher Michel Foucault. This framework supports an investigation of the re-spatialization of work along three dimensions (discursive construction, instrumental materialization, and embodied experience). An illustrative vignette applies this framework to an example of a real company that has encouraged a policy of part-time work in coworking spaces for remote knowledge workers. The case shows how the re-spatialization (using coworking spaces as business centers) produces a specific disciplinarization of managerial norms. These findings suggest the need to rethink the relations among organizational space, materiality, and management control in a workspace hybridation context. In particular, this essay challenges the conventional contrast of corporate and coworking values, by showing that coworking spaces sometimes implicitly materialize business values.
\end{abstract}

Keywords: despatialization-respatialization; hybridation; re-regulation of work; rematerialization; remote work; coworking space; Michel Foucault 


\section{Introduction}

Knowledge work has liquefied and is taking place elsewhere (Bauman, 2000; Bauman and Lyon, 2013; Salovaara, 2015), so that “work isn't where it used to be" (Blakstad, 2015). In a context of liquid modernity (Bauman, 2000), several interrelated factors break down the classic frontiers of organizations, including the increased importance of knowledge work and service industries (Drucker, 1988), the development of collaborative and networking information technologies and digitization (Castells, 1996; Orlikowski, 1991), the dematerialization of processes, greater awareness of employees' expectations and well-being, mobility and sustainability issues (Urry, 2007), cost and space pressures (Halford, 2005), and work "projectification" (Spinuzzi, 2015). Together these trends have prompted new working practices (Kingma, 2018), such as nomadic, mobile, flexible, distributed, remote, and teleforms of work (Sewell and Taskin, 2015). Such practices reflect work that increasingly gets performed outside typical physical, spatial, and temporal organizational boundaries (Salovaara, 2015).

From spatial, temporal, and material perspectives, the nature of work and organizations have changed dramatically, shifting from a strong centralization around the production tool or technology in $19^{\text {th }}$ century to the decentralization, "distantiation," and "despatialization" of work (Taskin, 2006, 2010), associated with virtualization and spatio-temporal dislocation (cf. co-location) by managers, subordinates, and peers (Halford, 2005). Beyond virtualization and "anytime-anywhere" rhetoric (Hislop and Axtell, 2009), we also observe a shift toward a "respatialization" of work in multiple, new locations (Halford, 2005), such as third workspaces (Kingma, 2016). This spatial reconfiguration (Hislop and Axtell, 20009) often results in workplace "hybridation" (Halford, 2005; Kingma, 2016), such that work occurs on client premises, in headquarters and classic offices, and in third workspaces. Despite the options for dematerializing and distantiating work from its material setting, organizations seek to respatialize work in new places (O'Brien, 2011), rematerialize it, and finally re-embed it in formal organizational settings. For example, Yahoo and IBM have encouraged their remote employees and teleworkers to abandon homeworking and go back to the office. Third workspaces (Kingma, 2016) offer appealing alternative workplaces for organizations too, in that they provide remote employees with a more productive setting than homes and also address the changing needs of new generations of workers (Salovaara, 2015).

With a few exceptions (Halford, 2005; Hislop and Axtell, 2009; Taskin and Edwards, 2007), this spatial reconfiguration of work has been poorly theorized, leaving with no answer to questions about the meaning and implications of the re-spatialization of work, even though such practices inevitably alter the social space of organizations (Lefebvre, 1991), that is, their territoriality and materiality (Halford, 2005; Sewell and Taskin, 2015). By modifying the spatial, temporal, and material frames of work, these practices imply a "re-regulation" (i.e., reorganization of the conduct of work; Edwards et al., 2002), with various effects for social, managerial, and power relations (Dale, 2005; Dale and Burrell, 2008; Sewell and Taskin, 2015). Noting the proliferation of new places of work, this study focuses on the re-spatialization and re-regulation of remote work in coworking spaces, which companies increasingly use to rematerialize the activity of their remote employees. 
Coworking spaces initially sought to appeal primarily to freelancers, entrepreneurs, start-ups, and micro-enterprises (Salovaara, 2015), but companies also find them attractive (Saiidi, 2017). Although there is no consensus academic definition of coworking, it generally constitutes a new category of flexible workspace, or third workspace (Kingma, 2016), between private homes and corporate offices. Coworking thus offers a new category of flexible work or perhaps the next generation of telework (Kingma, 2016); it designates a new form of organizing collaborative work according to a novel spatiality. By leveraging the "unoffice" (Spinuzzi, 2012a, p.412), coworking becomes "part of a larger movement toward distributed work and perhaps a way to examine and predict further work trends" (Spinuzzi, 2012b). No clear typology exists, but different types of coworking spaces can be distinguished, including shared spaces (which host entrepreneurs or freelancers who initiate their development) versus coworking business spaces (which are developed by and for organizations; Kingma, 2016). The use of third workspaces is "equally divided over informal spaces and specialized business centers" (Kingma, 2016, p. 176; Strelitz, 2011). With these alternative workplaces, companies can recreate, at a distance, connections with remote employees, provide them with a more productive environment than home, and avoid the sense of isolation felt by many homeworkers. These spaces also may provide opportunities for autonomy, flexibility, trust, knowledge sharing, and serendipitous encounters (Kingma, 2016; Spinuzzi, 2012a, 2012b).

Even with the popular enthusiasm coworking spaces have generated, relevant organizational research remains limited (Salovaara, 2015). Studies on third spaces have developed rapidly (de Vaujany et al., 2018; Garrett et al., 2014, 2017; Johns and Gratton, 2013; Waber et al., 2014); far fewer investigations consider the use of coworking spaces by companies and their employees (Kingma, 2016; Salovaara, 2015). To address this underresearched context of workplace hybridation, we investigate the physical re-territorialization of nomadic working practices (Gandini, 2015; O'Brien, 2011) in coworking spaces to determine: What does the respatialization of work in coworking spaces mean? What kind of re-regulation of work is implied by the re-spatialization of knowledge workers' activity in coworking spaces?

In this chapter, we seek to make sense of these questions by placing the re-spatialization of work within a framework of organizational politics. We propose a symbolic/narrative, material, and experienced tryptic, based on the French philosopher Michel Foucault's (1970, 1973, 1977, 1980, 1985a, 1985b) thought. Accordingly, we investigate the re-spatialization of activity by remote employees in coworking spaces along three dimensions: a symbolic/narrative dimension, with a consideration of space as a discursive construction; a material dimension, in which space is an instrumental materialization; and an experienced dimension, such that space represents an embodied experience. Next we apply the framework to an illustrative case, detailing the experience of a real company that instituted a policy for part-time work in coworking spaces among its remote knowledge workers. This example is not representative of all types of work hybridation, re-spatialization, or re-regulation of work in coworking spaces. Rather, it is indicative and illustrative (Hislop and Axtell, 2009), supporting our attempt to understand, in this specific context, what the re-spatialization of the activity of remote knowledge workers in coworking spaces implies for work re-regulation (Edwards et al., 2002). We do not aim to generalize our observations but rather to illustrate, with a specific example, the conditions, meaning, and implications of the understudied phenomena of workplace 
hybridation and work re-regulation in a context marked by the re-spatialization of remote work practices.

We start with an overview of relevant literature on work distantiation, hybridation, respatialization, and re-regulation. Our conceptual framework is based on a narrative, material, and experienced Foucauldian tryptic of social space. The application reflects an example of respatialization of the activity of remote workers in coworking spaces. We analyze our main findings, in particular how the distantiation and re-spatialization at stake in coworking spaces (used as business centers by the company) produce a specific, unsuspected disciplinarization of managerial norms. This study thus contributes to literature on de-spatialization (Taskin, 2006, 2010), re-spatialization (Halford, 2005), and re-regulation (Edwards et al. 2002) by advancing understanding of the conditions, implications, and tensions of new places of work, as well as issuing a challenge to rethink the relations among organizational space, materiality, and management control in the context of workspace hybridation. In particular, this essay challenges the widely assumed dichotomy of corporate and coworking values (Salovaara, 2015); instead, coworking spaces sometimes implicitly adopt and materialize corporate and business values, even while using the rhetoric of novel, purely altruistic values.

\section{Work distantiation, re-spatialization, and re-regulation}

Despite their long history, traditional offices and fixed workspaces are no longer the norm (Salovaara, 2015). Distributed work practices, such as remote work, nomadism, telecommuting, telework, and project-based and virtual work (Errichiello and Pianese, 2016; Mark and Su, 2010; Spinuzzi, 2007) break down traditional spatial and temporal organizational boundaries and imply work distantiation (Taskin, 2010). This distantiation entails a qualitative shift from traditional forms of centralized social organizations toward more diffused, complex sets of social relations (Sewell and Taskin, 2015)

Research on virtual teams (Maznevski and Chudoba, 2000), homeworking, telework (Sewell and Taskin, 2015), and distributed work arrangements (Errichiello and Pianese, 2016) notes the shifts and "re-regulation" of work (Edwards et al., 2002) prompted by these practices, such as from direct supervision to distance management, from face-to-face to technology-mediated communication, and from co-located teams to virtual collaborations (Errichiello and Pianese, 2016; Bailey and Kurland, 2002). The conclusions of such studies vary though. Some investigations see telework as a way to improve autonomy, flexibility, and trust, such that it diminishes disciplinary forces, loosens the reins of both managerial and peer control, and grants employees new opportunities to exercise autonomy at a distance (Felstead et al., 2003; Illegems and Verbeke, 2004; Mello, 2007). But other findings emphasize how such practices can paradoxically link to symbolic reconstructions of norms associated with the classic workplace, such as visibility, presence, trust, and availability (Halford, 2005; Orlikowski and Scott, 2008; Sewell and Taskin, 2015).

Remote work arrangements and virtual working have been a primary research focus (Brocklehurst, 2001; Kurland and Cooper, 2002; Sewell and Taskin, 2015); the hybridation of workplaces and re-spatialization of work in various spaces have been less studied (cf. Halford, 2005). In addition to supporting "anywhere-anytime" work concepts (Hislop and Axtell, 2009), 
information technologies can prompt spatial reconfigurations toward more hybridity (Halford, 2005; Sewell and Taskin, 2015), such that work gets performed in a mix of settings and spaces (e.g., domestic space, organizational space, and cyberspace) (Halford, 2005; Hislop and Axtell, 2009), including new places of work like third workspaces (Kingma, 2016; Oldenburg, 1989).

Yet even when they recognize the possibilities of work dematerialization and distantiation, organizations often re-embed and re-spatialize work in formal physical and material settings. For example, new technologies enable virtual organizational structures and relationships that operate with little or no face-to-face contact (Halford, 2005), such that organizations become "edgeless" and "permeable" (Davidow and Malone, 1992). Instead, organizations seem to reembed work in formal organizational settings by requiring employees to return to headquarters or regional offices, blurring the lines between office and living spaces (Fleming and Spicer, 2004), or encouraging remote workers to adopt more formal settings like third workspaces (Kingma, 2016; O'Brien, 2011; Salovaara, 2015). Such evolutions imply, ironically, that the future of work might mean returning to the office (Huber, 2017). At Yahoo for example, employees were banned from working from home in 2013, due to abuses of the remote work system, with the argument that "speed and quality are often sacrificed when we work from home" (Mayer, 2013, quoted by Smith, 2013). After years of distantiation and dislocation of its staff through telework, Yahoo sought a re-spatialization on the company's premises because "We need to be one Yahoo!, and that starts with physically being together" (Goudreau, 2013). Similarly, IBM pioneered telecommuting in the 1990s, then rejected the trend it helped start by asking thousands of employees to return to offices. As an alternative, coworking spaces give remote or homeworking employees a more productive setting in which to work (Salovaara, 2015).

Thus, even as virtual work gains prominence in the popular imagination, it remains rare and unpopular among managers (Taylor and Spicer, 2007). Organizations could become boundaryless, and might benefit from doing so, yet "managers continue to require physical presence in the workplace and ... performance is often judged on the amount of time spent 'at work" (Taylor and Spicer, 2007, p. 332). The main challenge to distantiation and despatialization thus seems to derive from the altered presence and visibility of employees (Felstead et al., 2003), which results in a double loss of physical and psycho-sociological proximity and an ability to manage people (Taskin, 2010). According to Taylor and Spicer (2007), remote work is hard to implement because managing as an activity is difficult to displace. Thus managers exhibit enduring reluctance and raise barriers to the adoption of remote work arrangements, because their managerial legitimacy and authority appears embedded in physical and psycho-sociological proximity (Halford, 2005). They also might fear losing visibility and control over employees, which may be why companies tend to re-spatialize work in more formal settings.

Furthermore, the hybridation and spatial reconfiguration of work alters employees' notions of visibility and invisibility, presence and absence, and colocation or dislocation, in both time and space and virtual or physical settings (Felstead et al., 2003; Halford, 2005). Thus it involves a novel re-regulation of work and reorganization of the conduct of work (Edwards et al., 2002; Taskin and Edwards, 2007) that requires new managerial practices, as well as revised social 
and power relations. We need a deeper investigation of the materiality and spatiality of new work practices (Dale, 2005), embedded in organizational politics, especially with regard to the way companies use coworking spaces for their own employees, in a way that tends to respatialize and re-materialize remote work and re-embed it in a physical space.

\section{Conceptual framework: A narrative, material, and experienced Foucauldian tryptic}

Paradoxically, despite the importance of space in work practices (Halford, 2005), it has long been absent from research in organization studies (Sewell and Taskin, 2015). Hypermobility (Urry, 2007), liquidity (Bauman, 2000), flexibility, and the ability to work "anytime, anyplace, anywhere" may have distracted researchers from the importance of spatial and material issues (Dale, 2005; Dale and Burrell, 2008; Halford, 2005; Sassen, 2000), even though, ironically, such practices have increased the meaning of physical places, at work and in managerial relations (Blakstad, 2015).

Although material places and the relation of physical and social space with management have not been treated conceptually at great length (Ropo et al., 2015), material aspects of organizational life, and space in particular, have regained interest in organization studies (Clegg and Kornberger, 2006; Dale, 2005; Dale and Burrell, 2008; de Vaujany and Mitev, 2013; Ropo et al., 2015; Van Marrewijk and Yanow, 2010). This so-called spatial turn, inspired by the materiality turn (Dale and Burrell, 2008; Kornberger and Clegg, 2005; Taylor and Spicer, 2007), has revived considerations of the spatial, material, and sociomaterial aspects of organizing, with the recognition that space offers a novel "source of thinking about social relations" (Sewell and Taskin, 2015, p. 1509). Organizational research highlights the influence of spatial and temporal dimensions on the nature and implications of work practices, proposing that the "where" and "when" intertwine to produce the "how" of working, such that "Where work is done makes a difference to working practices and to organizational and personal relationships" (Halford, 2005, p. 20). Spatial hybridity in particular changes the nature of work, organization, and management, because they get enacted in different spaces (e.g., domestic, organizational, virtual) (Halford, 20005), leading to a re-regulation of work that involves new ways to manage and control employees (Taskin and Edwards, 2007). Furthermore, power relations are central to understanding why organizations are spatially organized in certain ways (Taylor and Spicer, 2007). For example, offices and spaces represent devices of managerial regulation (Felstead et al. 2005; Taskin and Edwards, 2007). Therefore, re-spatialization should be embedded within an organizational politics frame. Because the spatial turn distinguishes objective, physically observable dimensions of space (architecture, design, technology) from its subjectively perceived dimension (emotionally felt by people) (Ropo et al., 2015), it demands research into both the physical design and spatial organization of work, as well as the values and symbolic meanings associated with re-spatialization, their effects on social relations and organizing at work, and the various ways space shapes power relations (Dale, 2005; Dale and Burrell, 2008; de Vaujany and Vaast, 2014; Halford, 2005; Sewell and Taskin, 2015).

We therefore propose a tryptical integrative framework, based on the spatial thinking detailed by Michel Foucault $(1970,1973,1977,1980,1985 a, 1985 b)$, to conceptualize a spatial and material view of the re-spatialization of the activities of remote employees in coworking spaces. As Foucault (1980, p. 70) recognized: "For generations in the social science, space was treated 
as the dead, the fixed, the undialectical, the immobility," and yet, "Space is fundamental in any form of communal life; space is fundamental in any exercise of power" (Foucault, 1984, p. 252). Using Foucault's integrative framework (Taylor and Spicer, 2007) enables an analysis of the significance of the physical working environment and its subjective meaning for organizational life, because for Foucault (1977, p. 148), spaces are "mixed spaces: real because they govern the disposition of buildings, rooms, furniture, but also ideal, because they are projected over this arrangement of characterizations, assessments, and hierarchies."

In particular, Foucault's framework suggests a more inclusive reconsideration of the notion of social space (Lefebvre, 1991), because it introduces issues of power, politics, control, hierarchy, identity, and emotions that have been excluded from previous analyses of social spaces (Lefebvre, 1991). It can support further elaboration on the distantiation (Taskin, 2006, 2010), re-spatialization, and re-regulation of work, which also have not been conceptualized in prior research.

To that end, we distinguish three main periods in Foucault's thought and approach to space (Burrell, 1998): archaeological (focused on symbolic/narrative dimensions, translated into discourses, rhetoric, and discursive practices), genealogical (focused on discipline and power relations embedded in the material), and ethical (or late Foucault, with a focus on the self, experiences, modes of subjectification, agency, and resistance). As a whole, the main concepts derived from these three periods anticipate the spatial turn and also support a rethinking of social spaces (Lefebvre, 1991), which can be opaque and ambiguous - and thus difficult to investigate empirically (Dale, 2005; Taylor and Spicer, 2007). As summarized in Table 1, we consider space as a discursive construction, such that we emphasize the discursive practices and narratives associated with specific spatial arrangements, physical manifestations, imaginary and expected uses of space, and the legitimation processes that underlie the construction or uses of such spaces. We also consider space as an instrumental materialization, highlighting power relations, hidden control, and influential and manipulative dynamics of materializing relations and planning and configuring that space. Finally, we denote space as an embodied experience, to emphasize the ways actors care for, experience, and emotionally feel, live, appreciate, and react to space and its embedded representations.

\begin{tabular}{|l|l|l|}
\hline Dimensions & Definition & $\begin{array}{l}\text { Parallel with classic dimensions } \\
\text { of social spaces }\end{array}$ \\
\hline $\begin{array}{l}\text { Space as a discursive } \\
\text { construction }\end{array}$ & $\begin{array}{l}\text { Discursive practices associated with } \\
\text { spatial arrangements physical } \\
\text { manifestations, imaginary aspects, } \\
\text { legitimation processes, and expected } \\
\text { uses of space. }\end{array}$ & $\begin{array}{l}\text { Spatial practices, perceived space } \\
\text { (Lefebvre, 1991); imagined space } \\
\text { (Taylor and Spicer) }\end{array}$ \\
\hline $\begin{array}{l}\text { Space as an } \\
\text { instrumental } \\
\text { materialization }\end{array}$ & $\begin{array}{l}\text { Power relations, hidden control, and } \\
\text { influential and manipulative dynamics } \\
\text { associated with the planning, design, } \\
\text { and configuration of space. }\end{array}$ & $\begin{array}{l}\text { Representations of space, } \\
\text { conceived spaces (Lefebvre, } \\
\text { 1991); spatial planning (Taylor } \\
\text { and Spicer, 2007) }\end{array}$ \\
\hline $\begin{array}{l}\text { Space as an embodied } \\
\text { experience }\end{array}$ & $\begin{array}{l}\text { Reflexive, critical, emotional } \\
\text { appreciation and reaction to a space and } \\
\text { its embedded representations, } \\
\text { providing meanings or feelings, and } \\
\text { ways to express one' sense of self. }\end{array}$ & $\begin{array}{l}\text { Spaces of representation, lived } \\
\text { spaces (Lefebvre, 1991); } \\
\text { practiced space (Taylor and } \\
\text { Spicer, 2007) }\end{array}$ \\
\hline
\end{tabular}


Table 1: Synthesis of Foucauldian dimensions of social space

With this framework, we investigate coworking spaces along three dimensions (space as a discursive construction, instrumental materialization, and embodied experience), while also taking organizational politics into account, with an illustrative example.

\section{Illustrative vignette}

An example of the re-spatialization of the activity of remote employees in coworking spaces

We investigated our main research questions through the lens of a narrative, material, and experienced Foucauldian tryptic, in the specific context of an exploratory, qualitative case study of a Belgian consulting company (as part of a larger project on the use of coworking spaces by companies). This company introduced a policy of part-time working in coworking spaces for its remote workers. They were encouraged to work in coworking spaces located in the main cities in Belgium that the company had previously identified. We explored their practices through guided tours, observations, and interviews (with remote employees, their manager, and three coworking space operators) conducted in three coworking spaces. For our data analysis, we applied a qualitative thematic analysis with a mixed and rich thematic coding process, using Nvivo software.

\section{The re-spatialization of work in coworking spaces as a discursive construction}

The re-spatialization of the activity of these remote employees in coworking spaces was logically presented by the company and the coworking space operators as a way to improve their autonomy, flexibility, and working conditions. Coworking spaces were discursively constructed by the coworking space operators and the company's managers as spaces of freedom, empowerment, knowledge sharing, and trust. They were presented as a new generation of workspace, apart from the home or office, that would enhance remote employees' well-being at work by providing them with a more flexible, better adapted work environment so that they could avoid isolation, reduce commuting times, and gain autonomy. These spaces also contributed to the diffusion of a renewed organizational culture, promoting forwardthinking and the well-being and self-control of employees, thus making the company more attractive for future hires.

As a coworking space operator explained, "these spaces provide fresh air compared to the office; they enable people to work differently, to change their posture towards work." They also were presented as "spaces offering a more professional environment for nomad workers and teleworkers than the home," together with social connections and a community. He described these spaces as "unexpected opportunities to unearth new markets, innovate, or collaborate in unexpected ways."

\section{The re-spatialization of work in coworking spaces as an instrumental materialization}

However, these spaces also appeared as concrete instrumental materializations (Dale, 2005) manipulated by the organization with two main objectives. The first was to create a sense of community, belonging, and togetherness among professionals, who often felt isolated (due to the enactment of materialized spaces and artifacts, as shown by the range of services offered in 
these workspaces). The spaces were crafted, from a material perspective, to cultivate informal relationships, socializing, information and knowledge sharing, trust, and a creative atmosphere (Fabbri and Charue-Duboc, 2013; Kingma, 2016).

The second objective was to create spaces of control that replicated office working conditions. Surprisingly, homeworking was not formally permitted in this company, so coworking spaces provided alternatives places of work that encouraged productivity, responsiveness, efficiency, and control, but beyond the physical boundaries of the company. The coworking space operators worked in close collaboration with the company and the manager to develop novel, indirect dispositifs of management and control (e.g., indicators of presence, use of a common electronic platform, technological tools such as intense reliance on instant messaging, formalization of meetings on specific days of the week). The company thus contributed to the re-regulation of work at distance (Taskin and Edwards, 2007). As notably summarized by the manager, "The workspace is a lever of performance, a real tool of management, which, when carefully thought, can result in more efficacy." A coworking space operator mentioned that that "the goal is to put a toolbox at the disposal of managers to help them really manage their team at a distance.... We put at their disposal many resources on the juridical and legal aspects of telework in coworking spaces and other tools of management and supervision to enable a distanced analysis of activities through the elaboration of credible and objective measures."

These new spaces of work thus were described as more convenient and providing more flexibility for remote employees, but they also enabled the company to exert indirect forms of control, based on presence and time management (e.g., when workers start or leave) and peer observation. Whereas third workspaces were discursively constructed as places of trust and emancipation, they were instrumentalized by the company to exert more precise control on the practices of their remote workers who are, by definition, outside of the presence of hierarchical control.

\section{The re-spatialization of work in coworking spaces as an embodied experience}

Finally, the enactment of these spaces produced different embodied experiences and relationships among the manager, remote employees, and coworking space operators, embedded in the way they used and perceived the spaces, which prompted some paradoxical tensions (i.e., relief or anxiety) (Sewell and Taskin, 2015). For some remote workers, the spaces re-created opportunities to signal their presence and engagement (Taskin and Edwards, 2007); for others, they introduced new constraints of availability, exposure, and visibility in third places intentionally designed for the purpose.

In the end, coworking spaces can be analyzed as materialized extensions of corporate settings at a distance, enabling work continuity, but in contradiction with the official discourse, which officially represented these new places of work as spaces of well-being, autonomy, and trust. Coworking spaces were used by the company as a way to re-spatialize and rematerialize the activity of its remote workers, "in a context where homework started to become widespread on Fridays," according to one of the coworking space operators. Paradoxically, these modern workspaces, based on notions of collaboration and openness, were not exempt from more conventional forms of control. 


\section{Re-spatialization in coworking spaces as a replication of corporate settings and re- materialization of remote work}

New ways of working suggest that work is mobile and unbound, but coworking spaces present an example of its re-spatialization; they thus are important places to study to understand what work in the digital age comprises. Although the current research has some limitations-we conducted an exploratory illustrative study, in the specific field of consulting (which is not representative of all professional contexts), with a single team, a single manager, and three third workspaces (which are not representative of all coworking spaces) - it also offers some novel insights. That is, even if our findings cannot be generalized, they provide a different, original angle on new ways of working and places of work, which highlights the ambiguities in the use of third workspaces by companies. This study contributes to a better understanding of the possible conditions and consequences of novel spatio-temporal designs and new places of work as new sources of tensions, which challenge us to rethink management control in a context of workspace hybridation, as well as the relationships among organizational space, materiality, management, and control. As Dale (2005, p. 651) notes, "little attention has been paid to the specific and explicit ways in which materiality is incorporated in social control, nor how forms of control are enacted and embodied on an everyday basis." Some studies indicate that materiality is relevant for understanding changing modes of control in organizational life (Dale, 2005; Dale and Burrell, 2008; de Paoli et al., 2017; Sewell and Taskin, 2015). Spaces also are implicated in the constitution of distinctive power relations, control, and resistance in workspaces (Dale, 2005). Dale and Burrell (2008, p. 43) refer, for example to "securing" and "obscuring" power in open-plan offices and emphasize the "latent power" of any built form that is visible in everyday practices, such that the manipulation of space is "achieved through keeping occupants ignorant of the sources and the operation of power" (Dale and Burrell, 2008, p. 45). The qualities and positive expectations of new places of work frequently get emphasized to create attention, attraction, and enchantment - especially as corporate strategies seek an image of "having creative workspaces" (de Paoli et al., 2019). Yet as demonstrated for the context of open spaces (de Paoli et al., 2017), spatial power is often exerted through the enchanting narrative of an open culture.

In this vein, our research highlights that coworking spaces are objects of discursive constructions that do not always correspond to the material configuration and underlying power relations of the space, leading to perceived tensions in the way people interpret, integrate, and use these third workspaces in their overall workspace. In particular, our analysis of the respatialization of the activity of remote employees in coworking spaces, through the adoption of a Foucauldian narrative, material, and experienced tryptic, highlights a new form of disciplinarization, at odds with the classic image of coworking spaces and telework. The distantiation and re-spatialization at stake in these coworking spaces (used by the example company as business centers) involves a re-regulation of work (Edwards et al., 2002) in the form of new bureaucratic protocols that reintroduce notions of visibility and presence at a distance, as well as produce a specific disciplinarization of managerial norms of efficiency, autonomy, and accountability. 
Although remote work and telework generally involve the "decoupling of work activity from one material workplace such as the office ... as well as from prescribed working hours, work schedules, scripts and practices" (Tietze, 2002, p.385; quoted in Taskin and Edwards, 2007), our case study reveals how the re-spatialization of remote work in coworking spaces provokes a move back. Paradoxically, the places we observed tended to make the activity of remote workers more predictable and to reinforce traditional bureaucratic virtues of surveillance, visibility, and control through the "superimposition of new practices of control on existing ones" (Taskin and Edwards, 2007, p. 204), which are contrary to the discourses about trust, emancipation, and flexibility often put forward about and within these spaces.

The rapid development of coworking spaces instead has been characterized by a "celebratory framework," a "vibe," and an "enthusiastic claim" (Gandini, 2015, p. 193), largely initiated by those who run and develop these places. The founders of coworking spaces generally bring to the fore their "alternative nature" and "potential to change society," in what they call a "profound cultural revolution" (Vidaillet and Bousalham, 2018, p. 2). That is, coworking is commonly presented as a new form of work organization that enables collaboration opportunities and encourages a sense of community inside a shared space, gathering workers from different companies or even freelancers with different profiles and objectives (Johns and Gratton, 2013). Studies on coworking often tell positive stories about better opportunities for collaboration, innovation, knowledge sharing, serendipitous encounters, and creativity (Garrett et al., 2017; Johns and Gratton, 2013). These new places of work thus are full of hopes, in a global context that pretends to be moving work practices toward a more collaborative economy, holacracy (Bernstein et al., 2016; Robertson, 2015), liberated organizations (Carney and Getz, 2009), empowerment, and trust (Martin et al., 2013; Morris et al., 2016; Seibert et al., 2004). As such, third workspaces claim to be new places of work that make the office obsolete (Jones et al., 2009). On the contrary, our study reveals that the coworking spaces we studied replicated the corporate world and conventional working conditions at a distance (Mello, 2007). They thus re-materialized remote work and generated new tensions among the narrative, discursive, and symbolic practices developed around the coworking spaces; the real, effective spatial design and configuration coupled with materialized forms of instrumentalization; and the underlying management system and "hidden logic of control" that they suggest.

This study thus informs research on third workspaces, which have not been investigated in sufficient depth thus far. Nor have these new work practices been substantially contested (Lyons, 2016; Ramadier, 2017). In contrast with generally positive evaluations of the coworking movement, our study offers a different, more nuanced, critical view. Some research points to tensions and contradictions "under the surface" of coworking spaces (Gandini, 2015, p. 203; Vidaillet and Boulsalham, 2018, p. 5). But few contributions actually "dwell upon empirical findings and rarely offer a critical understanding” of these places (Gandini, 2015, p. 194). In particular, coworking spaces have been defined as spaces that evade and even transcend power relations (De Peuter et al., 2017), such that "Coworking is assumed to be benign and its operations of power are unquestioned" (De Peuter et al., 2017, p. 688). In line with Gandini's (2015, p. 203) call for organizational researchers to "seriously take into account the contradictory nature" of coworking spaces, this study seeks to detail the tensions and contradictions sometimes observed in these spaces, notably between the pretended "counter- 
corporate identity" of coworking and "its recapitulation of neoliberal norms" (De Peuter et al., 2017 , p. 687). In research that identifies an opposition between coworking values and corporate norms (Spinuzzi, 2012a), a common proposition is that "those who chose coworking subscribe to coworking values, rather than corporate values" (Salovaara, 2015, p. 35), and recent studies show that some companies are adopting coworking values (Salovaara, 2015), as exemplified by IBM's experiment with non-territorial offices or Microsoft's reorganization of its open-plan offices. But the reverse is true as well. Our study adds depth to this assumed contrast between corporate and coworking norms and values, by showing that coworking spaces sometimes implicitly adopt and apply corporate and business values, even as they espouse a rhetoric of novel, purely altruistic values based on openness, well-being, flexibility, and collaboration.

Accordingly, this study contributes to literature on de-spatialization (Taskin, 2006, 2010), respatialization (Halford, 2005), and re-regulation (Edwards et al., 2002), by providing a counterpoint to the pretend revolution of coworking, showing that some practices and management principles remain the same, or even are re-regulated and reinforced, at a distance, with the image and rhetoric of a creative, modern, liberating working space. This finding is all the more striking when we note that the activity of remote knowledge workers generally is characterized by high skills, deregulated work, flexible arrangements, and strong commitment (Cooper and Kurland, 2002; Peters et al., 2004). In turn, we call for further research that conceptualizes the underlying reasons and implications of such a re-spatialization and rematerialization of remote work.

\section{References}

Bailey, D.E., \& Kurland, N.B. (2002). A review of telework research: Findings, new directions, and lessons for the study of modern work. Journal of organizational behavior, 23(4), 383-400.

Bauman, Z., (2000). Liquid Modernity. Cambridge: Polity.

Bauman, Z., \& Lyon, D. (2013). Liquid surveillance: a conversation. New York: John Wiley \& Sons.

Bernstein, E., Bunch, J., Canner, N., \& Lee, M. (2016). Beyond the holacracy hype. Harvard Business Review, 94, 38-49.

Blakstad, S.H., (2015). Work isn't where it used to be, in Leadership in Spaces and Places, (pp. 49-68). Cheltenham: Edward Elgar Publishing.

Brocklehurst, M. (2001). Power identity and new technology homework: Implications for 'new forms' of organizing. Organization Studies, 22, 445-466.

Burrell, G. (1998). Modernism, postmodernism and organizational analysis: The contribution of Michel Foucault. In A. McKinlay \& K. Starkey (Eds.), Foucault, Management and Organizational Theory (14-28). London: Sage.

Carney, B.M., \& Getz, I. (2009). Freedom, Inc.: Free your employees and let them lead your business to higher productivity, profits, and growth. New York: Crown Business. 
Castells, M. (1996). The Rise of the Network Society, Vol. 1, The Information Age: Economy, Society and Culture. Oxford: Blackwell Publishing.

Clegg, S. and Kornberger, M. (eds.) (2006). Space, Organization and Management Theory. Copenhagen: Copenhagen Business School Press.

Cooper, C. D. and Kurland, N. B. (2002). Telecommuting, professional isolation, and employee development in public and private organizations. Journal of Organizational Behavior, 23(4), 511-532.

Dale, K. (2005). Building a social materiality: Spatial and embodied politics in organizational control. Organization, 12, 649-678.

Dale, K., \& G. Burrell. (2008). The Spaces of Organisation and the Organisation of Space: Power, Identity and Materiality at Work. Houndmill, Basingstoke and New York: Palgrave Macmillan.

Davidow, W. \& M. Malone (1992). The Virtual Corporation. London: Harper Collins.

de Paoli, D., Sauer, E., \& Ropo, A. (2017). The spatial context of organizations: A critique of 'creative workspaces'. Journal of Management \& Organization. Published online by Cambridge University Press: 18 September 2017, https://doi.org/10.1017/jmo.2017.46.

de Paoli, D., Sauer, E., \& Ropo, A. (2019). The spatial context of organizations: A critique of 'creative workspaces'. Journal of Management \& Organization, 25(2), 331-352.

de Peuter, G., Cohen, N. S., \& Saraco, F. (2017). The ambivalence of coworking: On the politics of an emerging work practice. European Journal of Cultural Studies, 20(6), 687-706.

de Vaujany, F.-X. and Mitev, N. (2013). Materiality and space. Organizations, artifacts and practices. London: Palgrave.

de Vaujany, FX. \& Vaast, E. (2014). If these walls could talk: The mutual construction of organizational space and legitimacy, Organization Science, 25(3),713-731.

De Vaujany, FX., Dandoy, A., Grandazzi, A. and Faure, S. (2018). Experiencing a New Place as an Atmosphere: A Focus on Tours of Collaborative Spaces, Scandinavian Journal of Management, https://doi.org/10.1016/j.scaman.2018.08.001.

Drucker, P. (1988). The coming of the new organization. Harvard Business Review, JanuaryFebruary, 45-53.

Edwards, P., Geary, J. \& K. Sisson (2002). New forms of work organisation in the workplace: Transformative, exploitative, or limited and controlled? In G. Murray, J. Bélanger, A. Giles and P.-A. Lapointe (eds.) Work and employment relations in the high performance workplace (pp. 72-119). London: Continuum.

Errichiello L., \& Pianese T. (2016). Organizational control in the context of remote work arrangements: a conceptual framework. In Widener S., Epstein M., Verbeeten F. (eds.), Performance Measurement and Management Control: Contemporary Issues, 31, (pp. 273-305). Bingley: Emerald Publishing. 
Fabbri, J. \& Charue-Duboc, F. (2013). The role of physical space in collaborative workspaces hosting entrepreneurs: The case of the beehive in Paris. In F. de Vaujany, and N. Mitev (eds.), Materiality and Space. Organizations, Artefacts and Practices (pp. 117-134). Basingstoke: PalgraveMacmillan.

Felstead, A., Jewson, N. \& Walters, S. (2003). Managerial control of employees working at home. British Journal of Industrial Relations, 41(2), 241-264.

Felstead, A., Jewson, N. \& Walters, S. (2005). Changing Places of Work. London: Palgrave.

Fleming, P. \& Spicer, A. (2004). You can check out any time you want, but you can never leave: spatial boundaries in a high commitment organization. Human Relations, 57(1), 75-94.

Foucault, M. (1970). The order of things: An archaeology of the human sciences. London: Tavistock.

Foucault, M. (1973). The birth of the Clinic. London: Tavistock. Original French version 1963.

Foucault, M. (1977). Discipline and punish: The birth of the prison. New York: Random House.

Foucault, M. (1980). Power/Knowledge. London: Harvester Wheatsheaf.

Foucault, M. (1984). Space, knowledge and power. In Rabinow, P. (ed.) The Foucault reader. New York: Pantheon. 239-256.

Foucault, M. (1985a). The use of pleasure: The history of sexuality Volume 2. New York: Pantheon.

Foucault, M. (1985b). The care of the self: The history of sexuality Volume 3. New York: Pantheon.

Gandini, A. (2015). The rise of coworking spaces: A literature review. Ephemera - Theory and Politics in Organization, 15(1): 193-205.

Garrett, L. E., Spreitzer, G. M., \& Bacevice, P. A. (2017). Co-constructing a sense of community at work: The emergence of community in coworking spaces. Organization Studies, 38(6): 821-842.

Goudreau, J (2013). Back To the Stone Age? New Yahoo CEO Marissa Mayer Bans Working From Home. Available at: https://www.forbes.com/sites/jennagoudreau/2013/02/25/back-tothe-stone-age-new-yahoo-ceo-marissa-mayer-bans-working-from-home/\#33354ceb1667

(Accessed July 2 2017).

Halford, S. (2005). Hybrid workspace: Re-spatialisations of work, organisation and management. New Technology, Work and Employment, 20, 19-33.

Hislop D., \& Axtell, C. (2009). To infinity and beyond?: workspace and the multi-location worker. New Technology, Work and Employment 24:1, 60-75.

Huber, K. (2017). Does the future of work mean returning to the office? https://america.cgtn.com/2017/07/07/does-the-future-of-work-mean-returning-to-the-office 
Illegems, V., \& Verbeke, A. (2004). Telework: what does it mean for management?. Long Range Planning, 37(4), 319-334.

Johns, T. \& Gratton L. (2013). The third wave of virtual work. Harvard Business Review, January-February, pp. 66-73.

Jones, D., T. Sundsted, \& Bacigalupo, T. (2009). I'm Outta Here! How Coworking is Making the Office Obsolete, Austin, TX: Not an MBA Press.

Kingma, S. (2016). The constitution of 'third workspaces' in between the home and the corporate office. New Technology, Work and Employment, 31(2), 176-193.

Kingma, S. (2018). New Ways of Working (NWW): work space and cultural change in virtualizing organizations. Culture and Organization, 25, 1-24.

Kornberger, M. \& S. Clegg (2005). Bringing space back in organizing the generative building. Organization Studies, 25(7), 1095-1114.

Kurland, N.B., \& Cooper, C.D. (2002). Manager control and employee isolation in telecommuting environments. Journal of High Technology Management Research, 13(1), 107126.

Lefebvre, H. (1991). The Production of Space. Blackwell, Oxford.

Lyons D. (2016). Disrupted, My Misadventure in the Start-Up Bubble. Verlag: Hachette Books.

Mark, G., \& Su, N. M. (2010). Making infrastructure visible for nomadic work. Pervasive and Mobile Computing, 6, 1-12.

Martin, S., Liao, H., \& Campbell, E. (2013). Directive versus empowering leadership: A field experiment comparing impacts on task proficiency and proactivity. Academy of Management Journal, 56(5), 1372-1395.

Maznevski, M. \& Chudoba, K. (2000). Bridging space over time: global virtual team dynamics and effectiveness. Organization Science, 11(5), 473-492.

Mello, J. (2007). Managing telework programs effectively. Employee Responsibilities and Rights Journal, 19, 247-261.

Morris J., Farrell, C., \& Reed, M. (2016). The indeterminacy of 'temporariness': Control and power in neo-bureaucratic organizations and work in UK television. Human Relations, 69(12), $2274-2297$.

O'Brien, M. (2011). Finding a home for the "digital nomad". http://www.michelleobrien.net/wpcontent/uploads/2011/10/OBRIEN_Home_digital_nomad.p

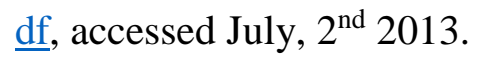

Oldenburg, R. (1989). The Great Good Place: Cafes, Coffee Shops, Community Centers, Beauty Parlors, General Stores, Bars, Hangouts, and How They Get You Through the Day. New York: Paragon House. 
Orlikowski, W.J. (1991). Integrated information environment or matrix of control? The contradictory implications of information technology. Accounting, Management and Information Technologies, 1(1), 9-42.

Orlikowski, W.J., \& Scott, S.V. (2008). Sociomateriality: Challenging the separation of technology, work and organization. Academy of Management Annals, 2 (1), 433-474.

Peters, P., Tijdens, K. \& Wetzels, C. (2004). Employees' opportunities, preferences, and practices in telecommuting adoption. Information \& Management 41, 469-482.

Ramadier M. (2017). Bienvenue dans le nouveau monde, comment j'ai survécu à la coolitude des startups. Paris : Premier Parallèle.

Robertson, B. (2015). Holacracy: The new management system for a rapidly changing world. New York: Henry Holt and Company.

Ropo, A., Salovaara, P., Sauer, E., \& de Paoli, D. (2015). Leadership in spaces and places. Cheltenham, UK ; Northhampton, MA: Edward Elgar Publishing.

Saiidi U. (2017). Coworking spaces aren't just for entrepreneurs anymore https://www.cnbc.com/2017/09/01/coworking-spaces-arent-just-for-entrepreneursanymore.html, accessed, October, $11^{\text {th }} 2018$.

Salovaara, P. (2015). What can the coworking movement tell us about the future of workplaces? In A. Ropo, P. Salovaara, E. Sauer, \& D. De Paoli (Eds.), Leadership in Spaces and Places (pp. 27-48). Cheltenham, UK and Northhampton, MA: Edward Elgar Publishing.

Sassen, S. (2000). Excavating power. Theory, Culture and Society 17(1), 163-170.

Seibert, S., Silver, S., \& Randolph, W. (2004). Taking empowerment to the next level: A multiple-level model of empowerment, performance, and satisfaction. Academy of Management Journal, 47(3), 332-349.

Sewell, G. \& Taskin, L., (2015). Out of sight, out of mind in a new world of work? Autonomy, control, and spatiotemporal scaling in telework. Organization Studies, 36(11), 1507-1529.

Smith, K. (2013). Here's The Confidential Memo Yahoo Sent Employees About Working From Home. https://www.businessinsider.com/yahoo-working-from-home-memo-2013-2?IR=T, accessed May, $24^{\text {th }} 2018$.

Spinuzzi, C. (2007). Guest editor's introduction: Technical communication in the age of distributed work. Technical Communication Quarterly, 16(3), 265-277.

Spinuzzi C. (2012a). Working alone together: coworking as emergent collaborative activity. Journal of Business and Technical Communication, 26(4), 399-441.

Spinuzzi, C. (2012b). Writing: Working alone, together [blog], http://spinuzzi.blogspot.com/2012/05/writing-working-alone-together.html, accessed January, $22^{\text {nd }} 2019$. 
Spinuzzi, C. (2015). All Edge: Inside the New Workplace Networks, Chicago, IL: University of Chicago Press.

Strelitz, Z. (2011). Why place still matters in the digital age. Third place working in easy reach of home. Business Report, ZZA Responsive User Environments.

Taylor, S. \& Spicer, A. (2007). Time for space: a narrative review of research on organizational spaces. International Journal of Management Reviews, 9(4), 325-346.

Taskin, L. (2006). Télétravail : Les enjeux de la déspatialisation pour le management humain (online). Revue Interventions économiques 34(2), 73-94.

Taskin, L. (2010). Déspatialisation: Un enjeu de gestion. Revue Française de Gestion, 36(202). 61-76.

Taskin, L., \& Edwards, P.K. (2007). The possibilities and limits of telework in a bureaucratic environment: Lessons from the public sector, New Technology, Work and Employment, 22(3), 195-207.

Urry, J., (2007). Mobilities. Cambridge: Polity.

Van Marrewijk, A.V. and Yanow, D. (2010). Organizational spaces. Rematerializing the workaday world. Cheltenham: Edward Elgar.

Vidaillet, B., \& Bousalham, Y. (2017). Coworking spaces as places where economic diversity can be articulated: towards a theory of syntopia. Organization, 1350508418794003.

Waber B., Magnolfi J. \& Lindsay G. (2014). Workspaces that move people. Harvard Business Review, 69-77. 